\title{
EFFICACY OF DIFFERENT PREDATORY PHYTOSEIID MITE SPECIES ALONE OR COMBINATION IN CHECKING THE TWO SPIDER MITE Tetranychus urticae KOCH UNDER LABORATORY CONDITION \\ Abdallah, A. A. \\ Agric. Zoology and Nematology Dept. Fac. Agric., Al - Azhar Univ.
}

\begin{abstract}
The suppression of spider mite, Tetranychus urticae Koch populations by three different life styles phytoseiid predatory mite species, Phytoseiulus macropilis (Banks), Amblyseius californicus (McGregor) and A. cucumeris (Oudemans) was examined to investigate their efficiency of each species either single, combined with another or with both species to control the spider mites in the laboratory on a lima bean disc.

The three predatory species showed different consumption capacities of egg and adult prey, egg production, survival of immature stages, progeny reaching adulthood, time to prey extinction and persistence after prey extinction. Phytoseiulus macropilis alone showed the highest number of eggs laid at the first day and prey egg consumption. Amblyseius californicus alone showed the highest daily eggs laid, the highest number of progeny reached adulthood and the longest survival time after the prey extinction. Even though $A$. cucumeris alone showed the higher number of adult prey consumption on the first day than Amblyseius californicus alone, it recorded the lowest prey egg consumption; number of eggs laid, number of progeny reached adulthood, the longest time for prey extinction and the shortest period of survival after the prey extinction. However, the shortest time required for the complete extinction of the prey population was the combination of $P$. macropilis with $A$. californicus except $P$. macropilis alone.
\end{abstract}

\section{INTRODUCTION}

The family Tetranychidae (spider mites) contains the most important phytophagous mite pests; which cause great economic loss to many crop species worldwide (So, 1991). The two-spotted spider mite, Tetranychus urticae Koch, is polyphagous and can devastate many crops (e.g. McMurtry et al., 1970; Walter and Proctor, 1999; Easterbrook et al., 2001; Abdallah et al., 2009).

The main control method is through the application of pesticides, whereas residual effects and developing pesticide resistance of pests are growing thus making other control methods were necessary. In recent years the roles of phytoseiids in the biological control of spider mites and other phytophagous mites have become more widely appreciated (McMurtry and Croft, 1997). Phytoseiid mites are greatly the most successful as biocontrol agents (McMurtry et al., 1970; Helle and Sabelis, 1985a; Amin el al., 2009), they can keep spider mite densities below economic thresholds in apple orchards (e.g. Schausberger, 1991). However, phytoseiid mite species can differ in life style, feeding habits, dispersal ability and levels of persistence in absence of prey pest, attributes that affect their efficiency and performance 
Abdallah, A. A.

as potential biocontrol agents. McMurtry and Croft (1997) suggested that four different life-styles have evolved in phytoseiid mites, based primarily on differences in food utilisation. The current study was conducted using three predatory mite species, one from each lifestyles: Phytoseiulus macropilis (type I), a specialised predator of species of genus Tetranychus; Amblyseius californicus (type II), a selective predator of tetranychid mites that often associate with spider mites that produce dense webbing; $A$. cucumeris (type III) which is generalist predator feeding on various mites, insect species and pollen.

Laboratory experiment was conducted, using $P$. macropilis, $A$. californicus and $A$. cucumeris, to investigate whether combined release of the specialist and generalist predators provides better biological control than releases of each species singly.

\section{MATERIALS AND METHODS}

Phytophagous mites, T. urticae, were cultured on the lima bean plants in the greenhouse. Three plants were put in a large tray $(50 \times 35 \times 20 \mathrm{~cm})$ and infested with 100 gravid spider mites. Each plant pot was placed on an empty inverted pot to avoid water logging the plant roots, as the tray contained water to prevent the mites from escaping. Two infested plants were replaced with fresh uninfested plants once a week to ensure the continuation of the culture.

Predatory mite species were reared on two-spotted spider mite T. urticae. $A$. californicus and $P$. macropilis were reared using methods modified from (McMurtry and Scriven, 1965), large plastic boxes $26 \times 15 \times 10 \mathrm{~cm}$. were used. Cotton pad were placed in the middle of each box, leaving a space provided with water as a barrier to prevent predatory mites from escaping. Excised bean leaves highly infested with $T$. urticae were provided every day as food source for mites. Water was added to the plastic pan whenever required, to prevent the mites from escaping. The culture units for all species were kept at room temperature $\left(25 \pm 3^{\circ} \mathrm{C}\right)$.

Experimental design: An experimental plastic box $(10 \times 10 \times 2 \mathrm{~cm})$ consisted of a bean leaf disc (5 $\mathrm{cm}$ diameter) kept upside down on a filter paper $(9 \times 9 \mathrm{~cm})$, which was placed on the same-sized saturated cotton wool $(1 \mathrm{~cm}$ thick). Water was replaced, as required, to prevent the mites from escaping and to keep the leaf disc turgid. A total of 64 experimental plastic boxes were divided into seven treatments and a control, with eight replicates in each treatment. The boxes were maintained in an incubator at $26 \pm 1^{\circ} \mathrm{C}$, $16 \mathrm{~L}: 8 \mathrm{D}$ photoperiod and $60 \pm 15 \% \mathrm{RH}$.

Experimental procedure: The experiment started with 100 eggs and 10 healthy gravid spider mite females placed on each leaf disc. To obtain eggs, leaf discs were infested with 13 healthy, gravid spider mite females for 24 hours. The number of eggs was adjusted to 100 by removing or adding eggs with a fine camel hair brush. Into each replicate a total of six predator females were introduced; six of a single species, three each for two species, and two 
each for three species as shown in Table 1. The control had 10 spider mite females and 100 spider mite eggs without any predatory mite species.

Data collection: The following parameters were recorded daily from each leaf disc under stereo binocular microscope: the number of eggs and adults of spider mites consumed, and to prey extinction, the production of eggs by predatory species, number of progeny reached adulthood as well as duration of predator persistence after prey extinction. The number of eggs and adult spider mites consumed were calculated using methods of (Abdallah, 2002).

Table 1: Predatory phytoseiid mite species composition of each treatment.

\begin{tabular}{|l|c|}
\hline Predatory female species & $\begin{array}{c}\text { No. of predatory } \\
\text { females from each } \\
\text { species }\end{array}$ \\
\hline Phytoseiulus macropilis $(\mathrm{p})$ & 6 \\
\hline Amblyseius californicus $(\mathrm{ca})$ & 6 \\
\hline Amblyseius cucumeris $(\mathrm{cu})$ & 6 \\
\hline P. macropilis and A. cucumeris $(\mathrm{p}+\mathrm{cu})$ & $3+3$ \\
\hline P. macropilis and A. californicus $(\mathrm{p}+\mathrm{ca})$ & $3+3$ \\
\hline A. californicus and A. cucumeris $(\mathrm{ca}+\mathrm{cu})$ & $3+3$ \\
\hline P. macropilis, A. cucumeris and A. californicus $(\mathrm{p}+\mathrm{ca}+\mathrm{cu})$ & $2+2+2$ \\
\hline Control (spider mites only) & 0 \\
\hline
\end{tabular}

Statistical analysis: Differences among treatments for all listed parameters, mean number of eggs and adults of spider mites consumed, time taken to extinction, production of eggs deposited for each predatory species separately and time of predatory persistence after prey extinction, were evaluated by one-way analysis of variance (ANOVA), whereas means were compared using Fisher's least significant difference (LSD), both performed by the Super ANOVA program (Gagnon et al., 1989). Values observed in mixed species treatments and the values expected on the basis of single species treatments were compared using Student's t-test. Significance was tested at $P \leq 0.05$.

\section{RESULTS}

Predation of adult spider mite females: There was significantly different adult prey consumption by the six adult predatory females on the first day $\left(F_{6,49}=35.86 ; P<0.001 ;\right.$ Table 2$)$, and it is ranked in descending order of: the combination of $P$. macropilis with $A$. cucumeris, $P$. macropilis alone equally to $A$. cucumeris alone, the combination of $P$. macropilis with $A$. californicus, the combination of all three species, the combination of $A$. californicus with $A$. cucumeris, $A$. californicus alone which exhibited the lowest adult prey consumption among all treatments (LSD; $P<0.001$ ). The observed value of adult prey consumption for the combination of $P$. macropilis with $A$. 
Abdallah, A. A.

californicus and the combination of all three species was significantly higher than the expected value $(P<0.01)$ calculated from the treatment single species data. Likewise, average daily adult prey consumption was significantly different among treatments $\left(F_{6,49}=4.362 ; P<0.01\right)$ and it is ranked in descending order of: the combination of $P$. macropilis with $A$. californicus equally to the combination of all three species, $P$. macropilis with A. cucumeris, $P$. macropilis alone, $A$. cucumeris alone equally to its combination with $A$. californicus and $A$. californicus alone, which consumed the lowest number of the adult prey (Table 2). The observed value of adult prey consumption for the combination of $P$. macropilis with $A$. californicus and the combination of all three species was significantly higher than the expected value $(P<0.01)$ calculated from the treatment single species data.

Table 2: Mean total consumption of ten adult spider mite females by different phytoseiid predators alone or in combination under laboratory condition

\begin{tabular}{|c|c|c|c|c|c|c|c|c|c|}
\hline \multirow[b]{2}{*}{ Treatments } & \multicolumn{3}{|c|}{ First day } & \multicolumn{3}{|c|}{ Second day } & \multicolumn{3}{|c|}{ Daily } \\
\hline & $\begin{array}{l}\text { D } \\
\stackrel{\$}{0} \\
\Phi \\
0 \\
0\end{array}$ & 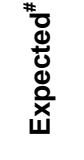 & के & 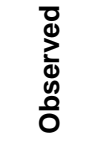 & 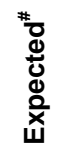 & के & 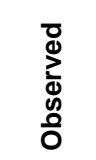 & 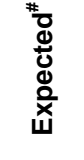 & के \\
\hline 1) ca (6) & $2.75_{c}$ & & 1.04 & $3.63_{a}$ & & 1.92 & $2.92_{c}$ & & 0.45 \\
\hline 2) p (6) & $6.88_{\mathrm{a}}$ & & 0.35 & $2.25_{b}$ & & 0.46 & $3.54_{a b c}$ & & 0.59 \\
\hline 3) $\mathrm{cu}(6)$ & $6.88 \mathrm{a}$ & & 0.64 & $2.13_{b}$ & & 0.64 & $3.33_{b c}$ & & 0.00 \\
\hline 4) $\mathrm{ca}+\mathrm{cu}(3+3)$ & $4.88_{b}$ & 4.81 & 0.83 & $3.63_{a}$ & 2.88 & 1.30 & $3.33_{b c}$ & $3.13^{*}$ & 0.00 \\
\hline 5) $p+c a(3+3)$ & $6.75 \mathrm{a}$ & $4.81^{\star}$ & 0.71 & $2.75_{a b}$ & 2.94 & 1.16 & $4.17_{\mathrm{a}}$ & $3.23^{\star}$ & 0.89 \\
\hline 6) $p+c u(3+3)$ & $7.13_{a}$ & 6.88 & 0.64 & $1.75_{b}$ & 2.19 & 0.71 & $3.75_{a b}$ & 3.44 & 0.77 \\
\hline 7) $p+c a+c u(2+2+2)$ & $6.63_{a}$ & $5.50^{*}$ & 0.92 & $2.50_{a b}$ & 2.67 & 1.31 & $4.17 \mathrm{a}$ & $3.26^{*}$ & 0.89 \\
\hline
\end{tabular}

Numbers of predatory individuals in each treatment are shown in brackets

Observed (means) in column followed by different subscript letters within columns are significantly different from each other $(P<0.05)$ LSD test

$\#:$ : Expected values of combined treatments were calculated as the observed values of the single treatments divided by the number of species involved, and compared using Student's t-test

*: Expected value is significantly different from observed value

Predation of immature (eggs and larvae) spider mites: The number of eggs consumed on the first day was significantly different among treatments $\left(F_{6,49}=27.26 ; P<0.001\right.$; Table 3$)$. Phytoseiulus macropilis alone or combined with $A$. californicus exhibited the highest egg predation (LSD; $P$ $<0.01)$. The next was $A$. californicus alone, which was followed by the combination of all three species, the combination of $P$. macropilis with $A$. cucumeris, the combination of $A$. cucumeris with $A$. californicus then $A$. cucumeris alone, which showed the lowest egg predation among all treatments (LSD; $P<0.05$ ), except its combination with A. californicus, the combination of $P$. macropilis with $A$. cucumeris and the combination of all three species $(P>0.05)$. The observed value of egg consumption for all combinations was significantly lower than the expected value $(P<0.01)$ except the combination of $P$. macropilis with $A$. californicus $(P=0.354)$. 
Average daily immature (eggs and larvae) consumption was significantly different among treatments $\left(F_{6,49}=19.19 ; P<0.001\right)$. The highest immature consumption was recorded in case of $P$. macropilis with $A$. californicus which was significantly different from all other treatments (LSD; $P<0.05$ ), except $A$. californicus alone (LSD; $P=0.100$ ). They were followed by $P$. macropilis alone, then the combination of all three species and $P$. macropilis with $A$. cucumeris. Next was $A$. cucumeris with $A$. californicus. Amblyseius cucumeris alone exhibited the lowest immature consumption among all treatments (LSD; $P<0.001$; Table 3).

Table 3: Mean total consumption of immature spider mite stages by different phytoseiid predators alone or in combination under laboratory condition

\begin{tabular}{|c|c|c|c|c|c|c|c|c|c|}
\hline \multirow[b]{2}{*}{ Treatments } & \multicolumn{3}{|c|}{ First day } & \multicolumn{3}{|c|}{ Second day } & \multicolumn{3}{|c|}{ Daily } \\
\hline & 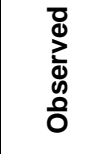 & 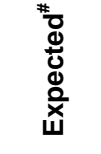 & ஸे & 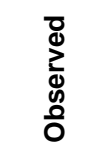 & 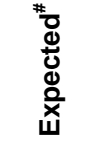 & ம & 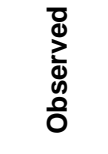 & 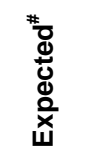 & ஸे \\
\hline 1) ca (6) & $108.20_{b}$ & & 6.78 & $85.17_{a}$ & & 15.64 & $78.34_{a}$ & & 4.96 \\
\hline 2) p (6) & $126.76_{a}$ & & 2.88 & $48.83_{c}$ & & 5.06 & $68.75_{b}$ & & 12.96 \\
\hline 3) cu (6) & $81.88_{c}$ & & 10.92 & $50.83_{c}$ & & 20.08 & $39.31_{d}$ & & 4.28 \\
\hline 4) $c a+c u(3+3)$ & $83.01_{c}$ & $95.61^{*}$ & 9.96 & $83.46_{a}$ & $68.00^{*}$ & 16.40 & $56.37_{c}$ & 58.82 & 6.19 \\
\hline 5) $p+c a(3+3)$ & $121.33_{\mathrm{a}}$ & 117.48 & 10.39 & $56.69_{b c}$ & 67.00 & 15.00 & $79.48_{a}$ & 73.54 & 16.05 \\
\hline 6) $p+c u(3+3)$ & $83.99_{c}$ & $104.88^{*}$ & 15.15 & $79.58_{a}$ & $49.83^{*}$ & 15.71 & $59.45_{b c}$ & 54.03 & 7.51 \\
\hline $\begin{array}{l}\text { 7)p+ca+cu } \\
(2+2+2)\end{array}$ & $88.40_{c}$ & 105.99* & 12.52 & $69.59_{\mathrm{ab}}$ & 61.61 & 13.48 & $59.78_{b c}$ & 62.13 & 2.25 \\
\hline
\end{tabular}

Numbers of predatory individuals in each treatment are shown in brackets

Observed (means) in column followed by different subscript letters within columns are significantly different from each other $(P<0.05)$ LSD test

\#: :xpected values of combined treatments were calculated as the observed values of the single treatments divided by the number of species involved, and compared using Student's t-test

*: Expected value is significantly different from observed value

Predatory egg production: The number of eggs laid by the six predatory females on the first day was significantly different among treatments $\left(F_{6,49}=\right.$ 42.46; $P<0.001)$. The highest eggs laid by the six predatory females was recorded in case of $P$. macropilis alone which was significantly different from all other treatments (LSD; $P<0.05$ ), except its combination with $A$. californicus and $A$. californicus alone (LSD; $P=0.100$ ). They were followed by the combination of all three species then the combination of $A$. cucumeris with $A$. californicus and $P$. macropilis with $A$. cucumeris. Amblyseius cucumeris alone deposited the lowest number of the eggs among all treatments (LSD; $P<0.001$; Table 4). The observed value of predatory egg production for the combination of $P$. macropilis with $A$. cucumeris or the combination of all three species together was significantly lower than the expected value $(P<0.01$; Table 4$)$ calculated from the individual species 
Abdallah, A. A.

data. Daily average of eggs produced by individuals in the treatments was significantly different $\left(F_{6,49}=30.94 ; P<0.001\right)$. The combination of $A$. californicus with $P$. macropilis showed significantly the highest number of eggs deposited on the daily average $(P<0.01$; Table 4), except $A$. californicus alone. They were followed by $P$. macropilis alone then $A$. californicus with $A$. cucumeris. Next was the combination of $P$. macropilis with $A$. cucumeris then the combination of the all three species. The lowest daily number of eggs deposited was recorded in case of $A$. cucumeris alone that was significantly different from all treatments (LSD; $P<0.01$ ). The observed value of predatory egg production for all the combination was significantly lower than the expected value $(P<0.01$; Table 4$)$ as calculated from the treatment single species data.

Overall daily changes in predator populations: Predatory populations increased exponentially through the first and the second day of the experiment in all the treatments except $A$. cucumeris alone, which continued to increase and reached peak density on the second day (Figure 1). Amblyseius californicus alone also continued to increase, reaching peak density on fourth day. After reaching their peak densities, predators in all treatments decreased sharply then at a lower rate until reaching their prey extinction (Figure 1).

Table 4: Number of eggs laid by different predatory phytoseiid speceis alone or in combination under laboratory condition

\begin{tabular}{|c|c|c|c|c|c|c|c|c|c|}
\hline \multirow[b]{2}{*}{ Treatments } & \multicolumn{3}{|c|}{ First day } & \multicolumn{3}{|c|}{ Second day } & \multicolumn{3}{|c|}{ Daily } \\
\hline & 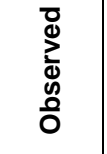 & 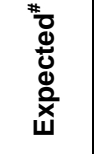 & के & 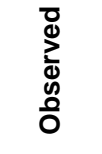 & 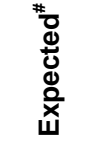 & œ & 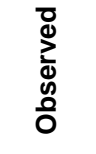 & 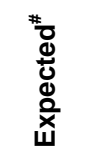 & œ \\
\hline 1) ca (6) & $20.13_{a}$ & & 1.13 & $20.88_{a}$ & & 3.14 & $11.00_{\mathrm{a}}$ & & 1.39 \\
\hline 2) p (6) & $21.63_{a}$ & & 2.62 & $13.00_{b}$ & & 4.00 & $8.73_{b}$ & & 1.25 \\
\hline 3) cu (6) & $11.88_{\mathrm{c}}$ & & 1.89 & $2.13_{e}$ & & 1.46 & $4.42_{\mathrm{e}}$ & & 0.53 \\
\hline 4) $c a+c u(3+3)$ & $15.13_{b}$ & 16.00 & 1.25 & $10.38_{c}$ & 11.50 & 2.13 & $7.01_{\mathrm{cd}}$ & 7.71 & 0.68 \\
\hline 5) $p+c a(3+3)$ & $20.25 a$ & 20.88 & 1.49 & $15.25 a$ & 16.94 & 1.49 & $11.15_{a}$ & 9.86 & 2.23 \\
\hline 6) $p+c u(3+3)$ & $14.13_{b}$ & $16.75^{\star}$ & 1.36 & $7.50_{d}$ & 7.56 & 2.39 & $6.77_{d}$ & $6.57^{\star}$ & 0.85 \\
\hline 7) $p+c a+c u(2+2+2)$ & $15.38_{b}$ & $17.88^{*}$ & 0.92 & $7.50_{d}$ & $12.00^{*}$ & 2.27 & $6.28_{d}$ & $8.05^{\star}$ & 0.98 \\
\hline
\end{tabular}

Numbers of predatory individuals in each treatment are shown in brackets Observed (means) in column followed by different subscript letters within columns are significantly different from each other $(P<0.05)$ LSD test

\#: : Expected values of combined treatments were calculated as the observed values of the single treatments divided by the number of species involved, and compared using Student's t-test

*: Expected value is significantly different from observed value

Maximum number of predator progeny reaching adulthood per female: The maximum number of progeny reaching adulthood produced by a female $A$. californicus alone was significantly different from its combination with other predator species $\left(F_{3,28}=44.859 ; P<0.001\right)$. Its maximum increase was recorded on seventh day (2.233 \pm 0.41 adult progeny individual per female), 
then started to decrease until day 15 to reach less than half of its original number. Next was its combination with $P$. macropilis, which increased on seventh day ( $2.95 \pm 0.21$ adult progeny individual per female; Figure 2$)$. Then numbers started to decrease until reaching extinction on twentieth day. Its combination with $A$. cucumeris and with $P$. macropilis together showed the lowest maximum number of progeny reached adulthood, which were less than half of their original numbers. Then numbers started to decrease until extinction of both on twentieth day. Maximum number of adult progeny per female $P$. macropilis alone was significantly different from its combination with other predator species $\left(F_{3,28}=32.718 ; P<0.001\right)$. Its maximum increase was recorded on sixth day (1.44 \pm 0.29 adult progeny), then started to decrease until reaching their extinction on eleventh day. Next was its combination with $A$. californicus ( $0.75 \pm 0.35$ adult progeny), which was recorded also on sixth day. Then started to decrease until reaching their extinction on tenth day. Its combination with A. cucumeris or with both other species together showed the lowest maximum number of adult progeny, which were less than 0.19 adult individual of their original numbers. Then started to decrease until their extinction on tenth and eleventh day respectively (Figure 2). The maximum number of progeny of $A$. cucumeris alone reaching adulthood was not significantly different from its combination with other predatory species $\left(F_{3,28}=0.416 ; P=0.407\right.$; Figure 2).

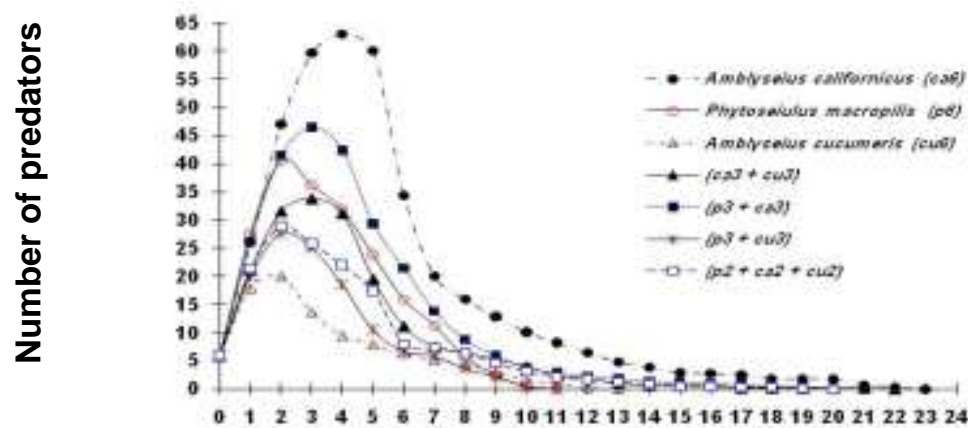

Time (days)

Figure 1: Population size of different predatory mite species through the experiment

Prey extinction time: Time to consume all ten adult prey individuals offered in the treatments was significantly different $\left(F_{6,49}=5.607 ; P<0.001\right)$. Contrary to the control group, the ten adult prey individuals offered in each treatment decreased (Figure 3).Adult prey consumption was different among the treatments, being highest in the combination of $P$. macropilis with $A$. 
Abdallah, A. A.

californicus which reduced the number of adult prey to only half individual on second day, then driven to zero ( $2.50 \pm 0.53$ days; Figure 3 and Table 5). On the other hand, in case of $A$. californicus alone, the adult prey decreased to 3.63 adult prey individuals on second day and then driven to zero (3.50 \pm 0.53 days; Figure 3 and Table 5). Time to consume the whole prey eggs was different among treatments $\left(F_{6,49}=23.042 ; P<0.001\right)$. Contrary to the control group, all treatments showed a decrease in immature prey, sharply for the combination of $P$. macropilis with $A$. californicus and $A$. californicus alone reaching immature prey extinction by third day as shown in Figure 4 and Table 5. Extinction time in the rest of the treatments was achieved after three days for the combination of all three species, the combination of $P$. macropilis with $A$. cucumeris, $A$. californicus alone and its combination with $A$. cucumeris. For $A$. cucumeris alone, the immature prey extinction time was reached after fourth day.

Table 5: Effect of single or combined predatory phytoseiid species on extinction time of spider prey under laboratory condition

\begin{tabular}{|c|c|c|c|c|c|c|c|c|c|}
\hline \multirow[b]{2}{*}{ Treatments } & \multicolumn{3}{|c|}{ Adult stage } & \multicolumn{3}{|c|}{ Immature stages } & \multicolumn{3}{|c|}{ All stages } \\
\hline & 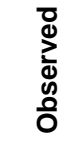 & 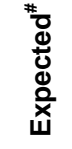 & மे & 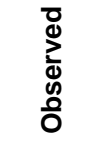 & 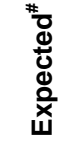 & œ & $\begin{array}{l}\text { D } \\
\stackrel{\$}{0} \\
\Phi \\
0 \\
0 \\
0\end{array}$ & 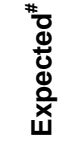 & ஸे \\
\hline 1) ca (6) & $3.50_{c}$ & & 0.53 & $3.38_{c d}$ & & 0.52 & $3.50_{c d}$ & & 0.53 \\
\hline 2) $p(6)$ & $2.88_{a b}$ & & 0.35 & $2.75_{a b}$ & & 0.46 & $2.75_{a b}$ & & 0.46 \\
\hline 3) cu (6) & $3.00_{b}$ & & 0.00 & $4.75_{\mathrm{e}}$ & & 0.46 & $4.75_{\mathrm{e}}$ & & 0.46 \\
\hline 4) $c a+c u(3+3)$ & $3.00_{b}$ & $3.25^{\star}$ & 0.00 & $3.75_{d}$ & 4.06 & 0.46 & $3.75_{d}$ & 4.13 & 0.46 \\
\hline 5) $p+c a(3+3)$ & $2.50 \mathrm{a}$ & $3.19^{\star}$ & 0.53 & $2.38_{a}$ & $3.06^{\star}$ & 0.52 & $2.50_{a}$ & $3.13^{*}$ & 0.52 \\
\hline 6) $p+c u(3+3)$ & $2.75_{a b}$ & 2.94 & 0.46 & $3.13_{b c}$ & $3.75^{\star}$ & 0.35 & $3.13_{b c}$ & $3.75^{*}$ & 0.35 \\
\hline 7)p+ca+cu $(2+2+2)$ & $2.50_{a}$ & $3.13^{*}$ & 0.53 & $3.13_{b c}$ & $3.63^{\star}$ & 0.35 & $3.13_{b c}$ & $3.67^{*}$ & 0.35 \\
\hline
\end{tabular}

Numbers of predatory individuals in each treatment are shown in brackets.

Observed (means) in column followed by different subscript letters within columns are significantly different from each other $(P<0.05)$ LSD test

$\#$ : :xpected values of combined treatments were calculated as the observed values of the single treatments divided by the number of species involved, and compared using Student's t-test

*: Expected value is significantly different from observed value

All spider mite prey extinction: The time taken by the different predatory phytoseiid mite species to drive all spider mite populations to zero was significantly different among treatments $\left(F_{6,49}=20.17 ; P<0.001\right)$. The combination of $P$. macropilis with $A$. californicus had the shortest time for spider mite extinction ( $2.50 \pm 0.52$ days; Table 5$)$, it was significantly different from all treatments (LSD; $P<0.05)$ except $P$. macropilis alone $(2.75 \pm 0.46$ days LSD; $P=0.134$ ). Next was the combination of $P$. macropilis with $A$. cucumeris, which was equally to the combination of all three species, and followed by $A$. californicus alone then the combination of $A$. californicus with $A$. cucumeris. The longest time for the spider mite extinction was recorded by A. cucumeris alone ( $4.75 \pm 0.46$ days; Table 5$)$. 


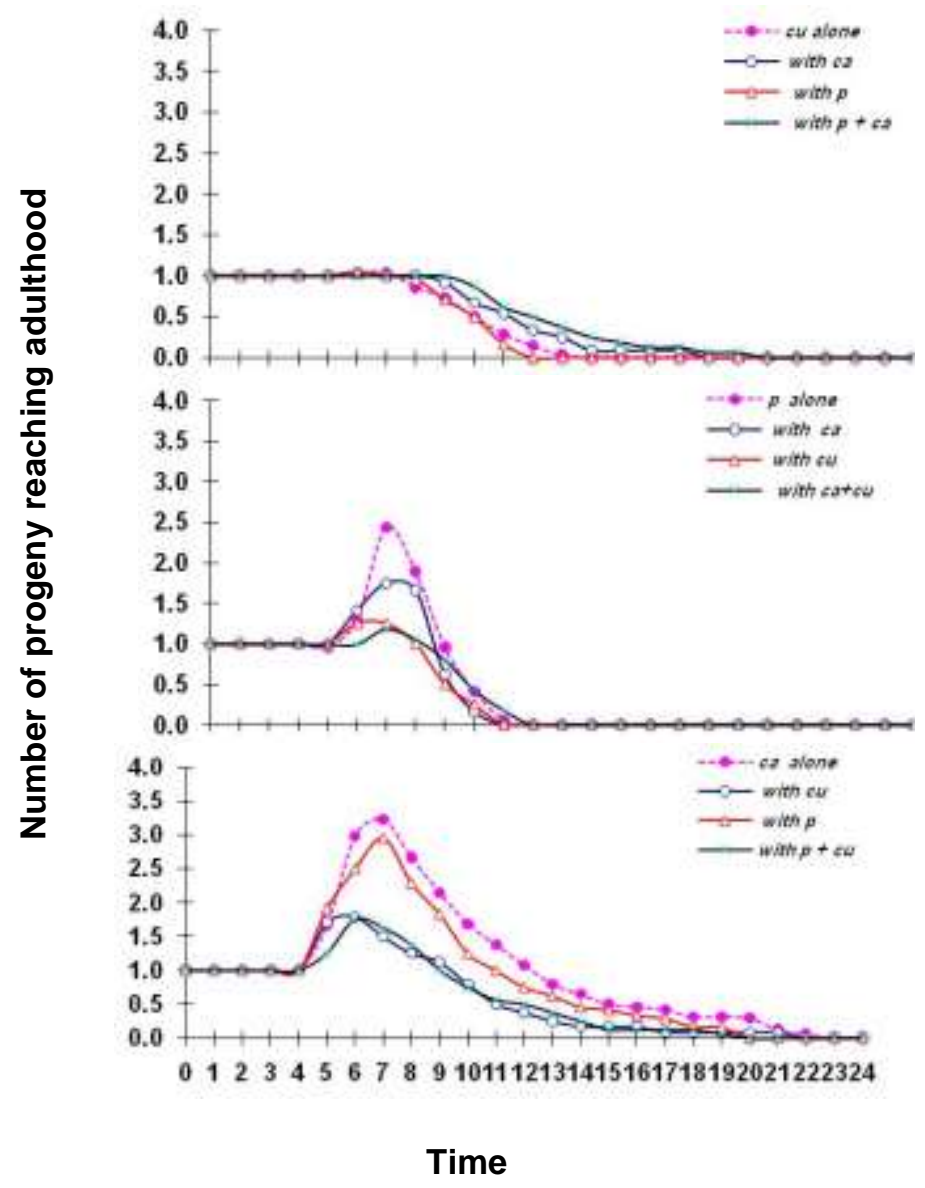

Figure 2: Number of progeny reaching adulthood per each predatory female used singly or combined with others 
Abdallah, A. A.

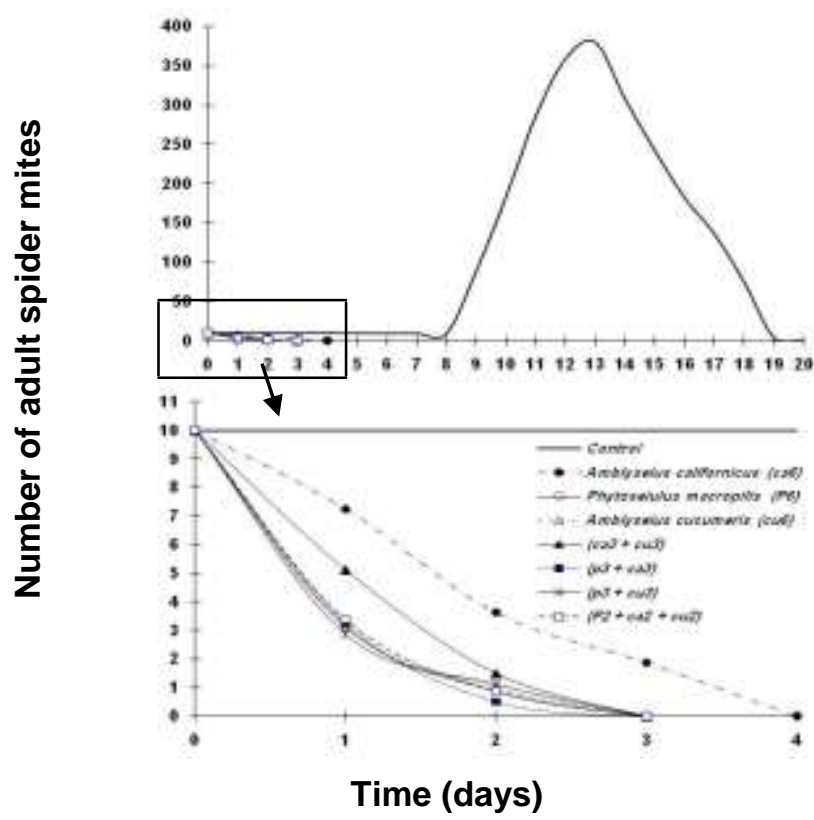

Figure 3: Effect of single or combined predatory species on extinction time of adult spider mite populations

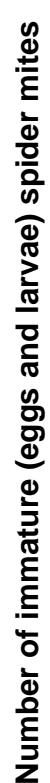
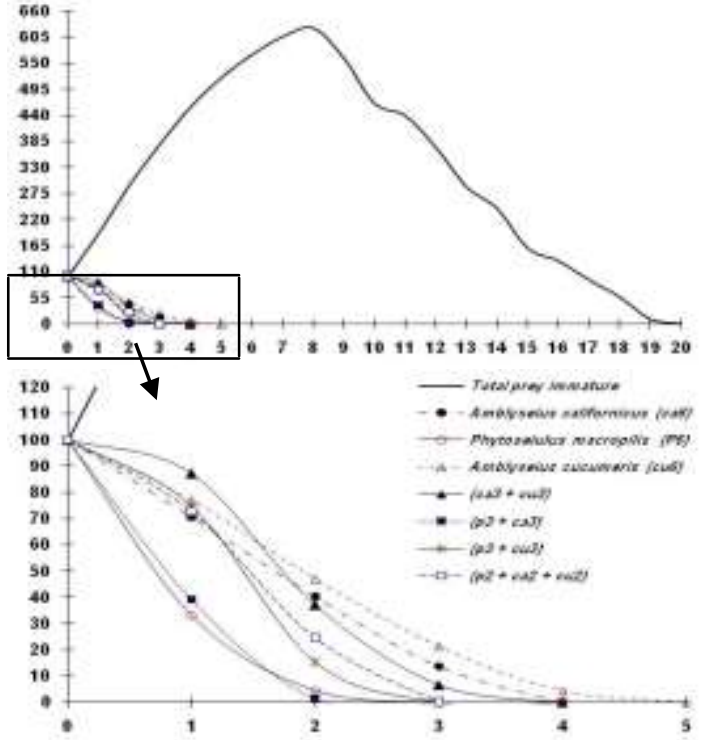

Time (days)

Figure 4: Effect of single or combined predatory species on extinction time of immature spider mite populations 


\begin{tabular}{|c|c|c|c|}
\hline \multirow{2}{*}{ Treatments } & \multicolumn{3}{|c|}{ Survival of the predatory mites } \\
\hline & Observed & Expected $^{\#}$ & SD \\
\hline 1) ca (6) & $16.88_{a}$ & & 2.23 \\
\hline 2) p (6) & $7.50_{c}$ & & 0.76 \\
\hline 3) $\mathrm{cu} \mathrm{(6)}$ & $6.63_{c}$ & & 0.74 \\
\hline 4) $c a+c u(3+3)$ & $13.00_{b}$ & 11.75 & 3.78 \\
\hline 5) $p+c a(3+3)$ & $15.63_{a}$ & $12.19^{*}$ & 2.13 \\
\hline 6) $p+c u(3+3)$ & $6.75_{c}$ & 7.06 & 0.46 \\
\hline 7) $p+c a+c u(2+2+2)$ & $12.88_{b}$ & $10.33^{*}$ & 2.53 \\
\hline
\end{tabular}

Table 6: Time of predator persistence after prey extinction

Numbers of predatory individuals in each treatment are shown in brackets observed (means) in column followed by different subscript letters within columns are significantly different from each other $(P<0.05)$ LSD test

\#: : Expected values of combined treatments were calculated as the observed values of the single treatments divided by the number of species involved, and compared using Student's t-test.

*: Expected value is significantly different from observed value

\section{DISCUSSION}

In this study, the suppression of spider mite, T. urticae by three predatory phytoseiid mites showed different consumption capacity of prey eggs and adults, time to prey extinction, predatory eggs production, progeny that reached adulthood and predator persistence after prey extinction.

Generally, the shortest time to consume the whole spider mite populations (adult and their eggs) was recorded in case of the combination of $P$. macropilis with $A$. californicus which reduced the number of adult prey to zero (2.50 \pm 0.53 days; Figure 3 and Table 5$)$ due to their efficacy of food consumption as specilisation predators. On the other hand, in case of $A$. cucumeris alone, the egg prey decreased to zero ( $4.75 \pm 0.46$ days; Figure 4 and Table 5). This was probably due to act as a general predator. Also, that was the case for all spider mite prey consumption. Some prey eggs were laid inside the webs on the leaf discs and thus $A$. cucumeris could not reach them without being entangled in the webs, so some of the prey eggs were left until hatched and moved outside the webs therefore they were then easily consumed. Predation of $A$. cucumeris on $T$. urticae eggs is hampered on the leaf disc by the webbing of $T$. urticae. Since $T$. urticae is classified as ' $C W-u^{\prime}$ ', indicating that it produces a highly complicated and irregular web, (Saito, 1985). Several species of phytoseiids tend to become entangled in spider mite webs and to avoid them (McMurtry et al., 1970). The difficulties of reaching to hiding eggs made $A$. cucumeris alone showed the lowest first day and daily prey eggs consumption and so the longest time to extinct the prey population.

Even though prey eggs consumption by $P$. macropilis alone was the highest among treatments on the first day with no significant difference from 
Abdallah, A. A.

its combination with $A$. californicus, but the daily consumption of immature prey (eggs with some larvae) was the highest in case of $A$. californicus alone with no significant difference from its combination with $P$. macropilis. It could be interpreted as once the $A$. californicus eggs hatched to larvae, they shared their mothers in the consumption of the prey eggs hence increase the daily eggs consumption. On the other hand, the larvae of $P$. macropilis normally do not feed and thus do not affect the daily eggs consumption average. Three types of larvae are recognised in the Phytoseiidae based on their feeding habits: non-feeding, facultative, and obligatory (Zhang and Croft, 1994).

The shortest time to consume all immature prey (eggs with some larvae) was nearly equal in case of $A$. californicus alone and its combination with $P$. macropilis. The estimations of predatory species efficiency were made in comparison with the curves of prey populations. The spider mite population decreased sharply in case of the combination of $P$. macropilis with $A$. californicus and $P$. macropilis alone. They drove the spider mite populations to extinction after $2.38 \pm 0.52$ days; Table 5 . Generally, the predator species, which has ability to reach and avoid the prey defence ways, could control the prey and drove the prey population to extinction faster than others.

Either $P$. macropilis or $A$. californicus produced higher number of eggs than $A$. cucumeris. In spite of $P$. macropilis showed the highest number of eggs deposited during the first day, but the highest daily average was recorded in case of $A$. californicus alone that continued to deposit eggs even though the prey population was near to finish. Amblyseius californicus may require less prey than $P$. macropilis to produce eggs.

Amblyseius californicus alone, $P$. macropilis alone or their combination showed higher proportion of a stage survival than $A$. cucumeris alone or any combination involving $A$. cucumeris. It may be because $A$. cucumeris cannibalize the available of its and other's immature stages easier than prey eggs inside the webs. Since space is limited on the leaf, dispersal is not allowed and prey become scarce, the adult predators may feed on their immature. Cannibalism and interspecific predation are common among phytoseiids as a result of low prey densities (e.g. Zhang and Croft, 1995; Schausberger and Croft 1999). Some of phytoseiid mite species had a greatest tendency to cannibalize on eggs and larvae (Schausberger 1997).

The use of $A$. californicus or $P$. macropilis singly showed higher number of adult progeny than any combination involved $A$. cucumeris. Amblyseius californicus alone showed the highest maximum number of progeny per female reached adulthood. It could be because $A$. californicus prefer heterospecifics to conspecific, whereas $P$. macropilis consumed the same amount of conspecific as heterospecific eggs (Schausberger and Croft 1999). Also Walzer and Schausberger (1999) recorded that adult and nymphal $P$. macropilis fed more conspecific but less heterospecifics on larvae and protonymphs than did the corresponding stages of $A$. californicus. And thus more eggs of $A$. californicus had the chance to reach adulthood. While the lowest was recorded in case of $A$. cucumeris alone, which was not significantly different from its combinations with others. 
Predator persistence after prey extinction is often related to predator's capacity to survive on a variety of foods and to complete successfully with other predatory species, frequently of closely related taxa (Duso and Vettorazzo, 1999). Amblyseius californicus alone showed a strong capacity to survive after the prey extinction more than the other predatory species. Also any other combination involving $A$. californicus showed a long persistence time, but less than $A$. californicus alone. It could be due to the cannibalism of the immature stages started earlier before the prey extinction in case of combined treatment, while in case of $A$. californicus alone, the cannibalism of the predatory immature stages starts mainly after prey extinction, and thus give the adults of $A$. californicus alone more time to survive after the prey extinction. On the other hand, other species $P$. macropilis and $A$. cucumeris alone or their combination recorded the lowest survival time after the prey extinction. The most important parameters are fecundity, hatchability, oviposition period, female longevity, developmental rate, survivorship and sex ratio (Helle and Sabelis, 1985b). Even though A. cucumeris alone showed the higher number of adult prey consumption on the first day than Amblyseius californicus alone, it recorded the lowest egg prey consumption; number of eggs laid and number of progeny reached adulthood, the longest time for prey extinction and the shortest period of survival after the prey extinction.

The present results indicated that the combination of $P$. macropilis with A. californicus or $P$. macropilis used singly drove the prey population to extinction on the same shortest time in case of the present small-scale experiment. And this drive us to use the same technique in the next experiment with a larger scale in a system to check if these results will be the same case over a larger scale or not. It is also indicated that $A$. californicus used singly or combined with other species showed a good capacity to control spider mite population than $A$. cucumeris used singly.

\section{REFERENCES}

Abdallah, A.A. 2002. Potential of predatory phytoseiid mites to control phytophagous mites. Ph.D. Thesis, Imperial College, London Univ., UK, $237 \mathrm{pp}$.

Abdallah, A.A.; Habashi, H Nadia; Mahgoub, M.H.A and El-Saiedy, E.M.A. 2009. Population dynamics of the two spotted spider mites, Tetranychus urticae koch in relation to some specific chemical constituents of four pepper varieties leaves. Minufiya J. Agric. Res. Vol. 34 No. 6: 2179-2189.

Amin, M. M., Mizell R. F., and Flowers, R. W., 2009. Response of the predatory mite Phytoseiulus macropilis (Acari: Phytoseiidae) to pesticides and kairomones of three spider mite species (Acari: Tetranychidae), and non-prey food. Flo. Ent. 92(4): 554- 562. 
Abdallah, A. A.

Duso, C. and Vettorazzo, E. 1999. Mite population dynamics on different grape varieties with or without phytoseiids released (Acari: Phytoseiidae). Exp. Appl. Acarol. 23: 741-763.

Easterbrook, M.A.; Fitzgerald, J.D. and Solomon, M.G. 2001. Biological control of strawberry tarsonemid mite Phytonemus pallidus and twospotted spider mite Tetranychus urticae on strawberry in the UK using species of Neoseiulus (Amblyseius) (Acari: Phytoseiidae). Exp. Appl. Acarol. 25: 25-36.

Gagnon, J.; Roth, J.M.; Carroll, M; Haycock, K.A.; Plamondon, J.; Feldman, D.S. and Simpsoon, J. 1989. Super ANOV accessible general linear modelling. Abacus Concepts, Berkeley, CA.

Helle, W. and Sabelis, M.W. 1985a. World Crop pests: Spider mites, their biology, natural enemies and control, Vol: 1B. Elsevier, Amsterdam. $458 \mathrm{pp}$.

Helle, W. and Sabelis, M.W. 1985b. World Crop Pests: Spider mites, their biology, natural enemies and control, Vol: IA. Elsevier, Amsterdam, $405 \mathrm{pp}$.

McMurtry, J.A. and Croft, B.A. 1997. Life-styles of phytoseiid mites and their role in biological control. Ann. Rev. Ent. 42: 291-321.

McMurtry, J.A. and Scriven, G.T. 1965. Life-history studies of Amblyseius limonicus with comparative observations on Amblyseius hibisci (Acarina: Phytoseiidae). Ann. Ent. Soc. Am. 58: 106-111.

McMurtry, J.A.; Huffaker, C.B. and Van de Vrie, M. 1970. Ecology of tetranychid mites and their natural enemies: a review. 1. Tetranychid enemies, their biological characteristics and the impact of spray practices. Hilgardia 40: 331-390.

Saito, Y. 1985. Life types of spider mites, pp. 253-264. In World Crop Pests: Spider mites, their biology, natural enemies and control, Helle, W. and Sabelis, M.W. (eds), Vol. 1A. Elsevier, Amsterdam.

Schausberger, P. 1991. Vergleichende Untersuchungen zum Lebensverlauf, die Erstellung von Lebenstafeln und die Vermehrungskapazität von Amblyseius aberrans Oud. und Amblyseius finlandicus Oud. (Acari: Phytoseiidae). Pflanzenschutzber 52: 53-71.

Schausberger, P. 1997. Inter- and intraspecific predation on immatures by adult females in Euseius finlandicus, Typhlodromus pyri and Kampimodromus aberrans (Acari: Phytoseiidae). Exp. Appl. Acarol. 21: 131-150.

Schausberger, P. and Croft, B.A. 1999. Activity, feeding, and development among larvae of specialist and generalist phytoseiid mite species (Acari: Phytoseiidae). Envir. Ent. 28: 322-329.

So, P.M. 1991. Distribution patterns of and sampling plans for Tetranychus urticae Koch (Acari: Tetranychidae) on roses. Res. Popul. Ecol. 33: 229-243.

Walter, D. and Proctor, H.C. 1999. Mites ecology, evolution and behaviour. CABI Publishing. CAB international, Wallingford, Oxon OX10 8DE, UK, $321 \mathrm{pp}$. 
Walzer, A. and Schausberger, P. 1999. Predation preferences and discrimination between con- and heterospecific prey by the phytoseiid mites Phytoseiulus persimilis and Neoseiulus californicus. BioControl 43: 469-478.

Zhang, Z.Q. and Croft, B.A. 1994. A comparative life-history study of immature Amblyseius fallacis, $A$. andersoni, Typhlodromus occidentalis and T. pyri (Acari: Phytoseiidae) with a review of larval feeding patterns in the family. Exp. Appl. Acarol. 18: 631-657.

Zhang, Z.Q. and Croft, B.A. 1995. Intraspecific competition in immature Amblyseius fallacis, Amblyseius andersoni, Typhlodromus occidentalis and Typhlodromus pyri (Acari: Phytoseiidae). Exp. Appl. Acarol. 19: 65-77.

اختبار فاعلية أكاروس الفيتوسيدى

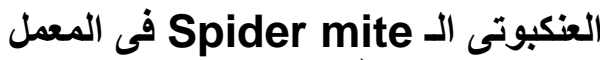

عوض على عبدالله قسم الحيوان الزراعى والنيماتودا، كلية الزراعه، جامعة الازهر بالقاهره

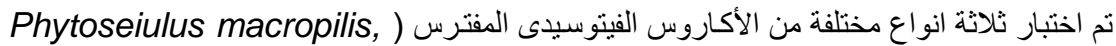

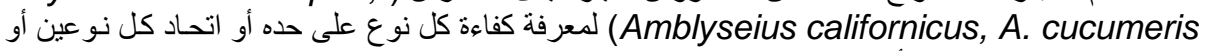

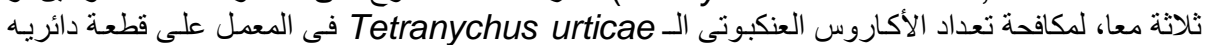

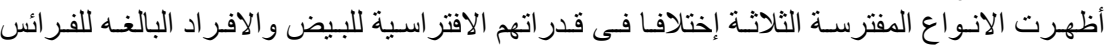

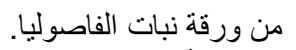

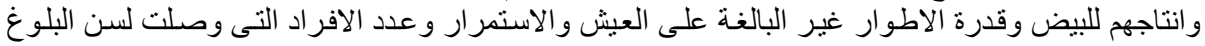

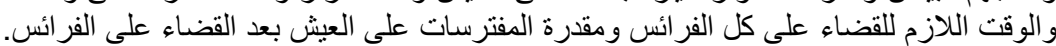

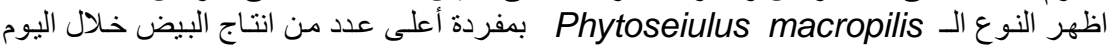

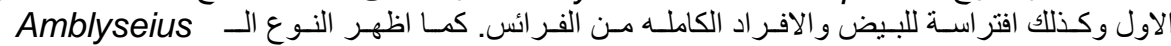
عalifornicus

و واظهر النوع الـ Amblyseius cucumeris بمفردة أعلى افتراس من الاطوار البالغة للفريسه

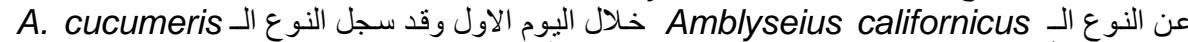

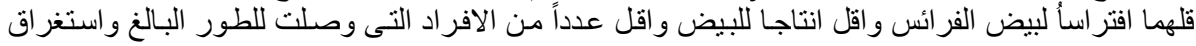

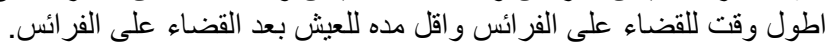

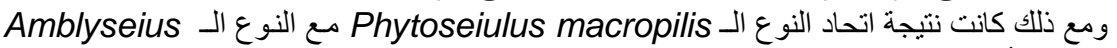

Phytoseiulus macropilis أسرع فى القضاء على كل الفرائس باستثناء النوع التوع الـ californicus

كلية الزراعة - جامعة المنصورة

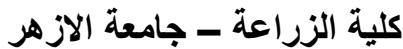

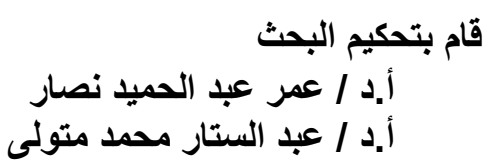

قام بتحكيم البحث

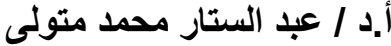

